Asian J. Med. Biol. Res. 2017, 3 (1), 103-108; doi: 10.3329/ajmbr.v3i1.32044

\author{
Asian Journal of \\ Medical and Biological Research \\ ISSN 2411-4472 (Print) 2412-5571 (Online) \\ www.ebupress.com/journal/ajmbr
}

\title{
Article
}

\section{Performance of some growth promoters on hybrid walking catfish (Clarias batrachus $\times$ Clarias gariepinus)}

\author{
Md. Sirazul Islam ${ }^{1}$, M. Mamnur Rashid ${ }^{1}$, Mohammad Shamsul Arefin ${ }^{2}$, Pronab Naha ${ }^{1}$ and Md. Rokanuddula ${ }^{1}$ \\ ${ }^{1}$ Department of Aquaculture, Faculty of Fisheries, Bangladesh Agricultural University, Mymensingh-2202, \\ Bangladesh \\ ${ }^{2}$ Department of Agricultural Extension Education, Faculty of Agriculture, Bangladesh Agricultural University, \\ Mymensingh-2202, Bangladesh
}

*Corresponding author: Md. Sirazul Islam, Department of Aquaculture, Faculty of Fisheries, Bangladesh Agricultural University, Mymensingh-2202, Bangladesh. Phone: +8801723877329 ; E-mail: sis.bau14@gmail.com

Received: 05 March 2017/Accepted: 20 March 2017/ Published: 30 March 2017

\begin{abstract}
A study was conducted to determine the efficacy of three most commonly used growth promoters from different pharmaceutical companies on growth performance of hybrid walking catfish (Clarias batrachus $\times$ Clarias gariepinus). The experiment was done in the wet laboratory of the Department of Aquaculture, BAU, Mymensingh, with a total of 10 aquaria and 160 fish having mean initial weight of $6.3 \pm 0.48 \mathrm{~g}$. The three growth promoters, "Charger gel" from Fishtech (BD) Ltd., "Growth gel" from Advance Agrotech (BD) Ltd. and "Hepaprotect-aqua" from Renata Animal health Ltd., were used in separate nine (9) aquaria at recommended, lower dose and higher dose respectively. One aquarium was used as control (diet without any growth promoter). The fish were fed with paragon nursery floating feed at $20 \%$ of body weight in each aquarium for 28 days. Doses of Charger gel were given as 80,60 and $100 \mathrm{mg} / 20 \mathrm{~g}$ feed/day, that of Growth gel, $0.14,0.12$ and 0.16 $\mathrm{ml} / 20 \mathrm{~g}$ feed/day and of Hepaprotect-aqua, 30, 15 and $50 \mathrm{mg} / 20 \mathrm{~g}$ feed/day. Re-circulatory system was used throughout the experimental period. By applying recommended, lower and higher dose of "Charger gel", mean final weights were found as 23.0, 21.9 and $35.9 \mathrm{~g}$; average daily weight gain as $0.60,0.56$ and $1.06 \mathrm{~g}$ and specific growth rate (SGR) as 2.01, 1.93 and $2.70 \%$ respectively. For "Growth gel", mean final weights were found as 22.8, 17.3 and $31.1 \mathrm{~g}$; average daily weight gain as $0.59,0.39$ and $0.88 \mathrm{~g}$ and SGR as $1.99,1.57$ and $2.48 \%$ respectively. For "Hepaprotect-aqua", mean final weights were found as 24.2, 17.5 and $28.2 \mathrm{~g}$; average daily weight gain as $0.64,0.40$ and $0.78 \mathrm{~g}$ and SGR as $2.09,1.58$ and $2.32 \%$ respectively. In all the cases survival rates were $100 \%$. All the three growth promoters showed better results at their higher doses in comparison to their results in lower and recommended doses. However, in average Charger gel showed the best result than the other two growth promoters. This information on the efficacy study of growth promoters needs to be disseminated to the farmers for improved fish production.
\end{abstract}

Keywords: growth promoters; dosage; performance; pharmaceutical companies

\section{Introduction}

Growth promoters are chemical and biological substances added to fish feed with the aim to improving fish growth (Tacon, 2014). It is used to enhance the digestion and thereby production by increasing growth rate, FCR as well as for improving defense mechanism and significant reduction in mortality. The use of such feed additives has been proven to be successful in aquaculture. It is necessary to fatten fishes and improve the utilization of food for better production and financial results. In Bangladesh aquaculture is rapidly spreading in recent years. Also, use of aqua-medicines for various purposes is widely recognized. Reasonably they are now 
essential components for intensive health management, feed formulation and growth promotion. It has been recognized that farmers have been using those aqua-drugs without knowing their efficacy. This is due to lack of information regarding the present status and consequence of aqua-drug use in aqua-health-development. So, it is necessary to test every group of growth promoters individually and present the expected results to the aquaculturists. After the introduction of growth promoters few researches have undertaken some works (Rahman et al., 2012; Chandra et al., 2013; Al-Mamun, 2013; Ariful et al., 2014; Mahmud, 2015) but their results were not adequate. In this point of view, it is necessary to evaluate the risk associated with the growth promoters and establish their standard doses and dosages which are in need to examine. The present study was conducted to determine the performances as well as the doses and dosages of some selected growth promoters for improving the growth of the hybrid walking catfish (Clarias batrachus $\times$ Clarias gariepinus).

\section{Materials and Methods}

\subsection{Experimental design}

The experiment was done in the wet laboratory of the Department of Aquaculture, Bangladesh Agricultural University, Mymensingh, with 10 aquaria and 160 fish for 28 days (27 May to 23 June 2016). Hybrid walking catfish (Clarias batrachus $\times$ Clarias gariepinus) was used. Average initial body weight of the fish was $6.3 \pm$ $0.48 \mathrm{~g}$. Total weight of fish in each aquarium was $100 \pm 3 \mathrm{~g}$ (15-16 fish). The size of each aquarium was $25 \mathrm{inch}$ $\times 12$ inch $\times 15$ inch. Total water holding capacity of each aquarium was 50 liters. All the aquaria were covered by a synthetic net to prevent fish from jumping out. The growth promoters were supplied at their recommended doses as well as at a dose lower and higher than the recommended doses. The three growth promoters together with their company name, composition and recommended mixing dose are presented in Table 1.

\section{Table 1. Description of three growth promoters.}

\begin{tabular}{llll}
\hline Trade name & Company name & Composition & $\begin{array}{l}\text { Recommended } \\
\text { mixing dose }\end{array}$ \\
\hline Charger gel & Fishtech (BD) Ltd. & $\begin{array}{l}\text { 1-3D beta glucons, betain, gluco proteins } \\
\text { from yeast cell walls and from other } \\
\text { natural sources }\end{array}$ & $4 \mathrm{~g} / \mathrm{Kg}$ of fish feed \\
Growth gel & $\begin{array}{l}\text { Advance Agrotech (BD) } \\
\text { Ltd. }\end{array}$ & $\begin{array}{l}\text { Essential vitamins, lysine methionine \& } \\
\text { herbs }\end{array}$ & $10 \mathrm{ml} / \mathrm{Kg}$ of fish feed \\
Hepaprotect-aqua & $\begin{array}{l}\text { Renata Animal health } \\
\text { Ltd. }\end{array}$ & $\begin{array}{l}\text { Beta glucan, mannon polymer and essential } \\
\text { oil }\end{array}$ & $1-2 \mathrm{~g} / \mathrm{Kg}$ of fish feed \\
\hline
\end{tabular}

Paragon nursery feed was supplied to the experimental fish. Three aquaria were used for each growth promoter: one with the recommended dose, one with lower and one with higher than recommended dose. One aquarium was kept as control where no growth promoter was added with the feed. Sampling was done by a scoop net at seven days interval. During each sampling 10 fish were collected from each aquarium very carefully to avoid any handling stress. The weight of fish was recorded by using an electronic balance. Temperature was measured every day by a Celsius thermometer and recorded as degree Celsius $\left({ }^{\circ} \mathrm{C}\right)$.

\subsection{Study of growth performances}

Following growth performances were studied.

Mean weight gain $(\mathrm{g})=$ Mean final fish weight $(\mathrm{g})$ - Mean initial fish weight $(\mathrm{g})$

Average daily gain $(\mathrm{g})=\frac{\text { Mean Final Weight }(\mathrm{g})-\text { Mean Initial Weight }(\mathrm{g})}{\mathrm{T}_{2}-\mathrm{T}_{1}}$

Where, $\mathrm{T}_{2}-\mathrm{T}_{1}=$ Duration of the experiment (day)

Specific growth rate $(\mathrm{SGR})(\% /$ day $)=\frac{\log \mathrm{W}_{2}-\log \mathrm{W}_{1}}{\mathrm{~T}_{2}-\mathrm{T}_{1}} \times 100$

Where, $\mathrm{W}_{1}$ was initial live body weight $\left(\mathrm{g}\right.$ ) at time $\mathrm{T}_{1}$ (day) and $\mathrm{W}_{2}$, final live body weight at time $\mathrm{T}_{2}$.

$\mathrm{T}_{2}-\mathrm{T}_{1}=$ Duration of the experiment (day)

Survival rate $(\%)=\frac{\text { No. of fish harvested }}{\text { No. of fish stocked }} \times 100$ 


\section{Results}

The results of the three different treatments with three different growth promoters and the control one are shown below. In all the cases survival rates were $100 \%$. The range of water temperature was $27-29{ }^{\circ} \mathrm{C}$, the average being $27.89 \pm 0.63{ }^{\circ} \mathrm{C}$.

\subsection{Effects growth promoters to average growth of fish after 28 days}

The average growth after 28 days of the experiment fish fed with growth promoter Charger gel with recommended dose, lower dose and higher dose were $23.0 \pm 2.67,21.9 \pm 1.91$ and $35.9 \pm 2.02 \mathrm{~g}$ respectively, with Growth gel, $22.8 \pm 2.44,17.3 \pm 1.77$ and $31.1 \pm 2.60$ g respectively, with Hepaprotect-aqua, $24.2 \pm 2.15$, $17.5 \pm 1.58$ and $28.2 \pm 1.87 \mathrm{~g}$ respectively and without growth promoter (Control) was $14.4 \pm 1.65 \mathrm{~g}$ (Figure 1).

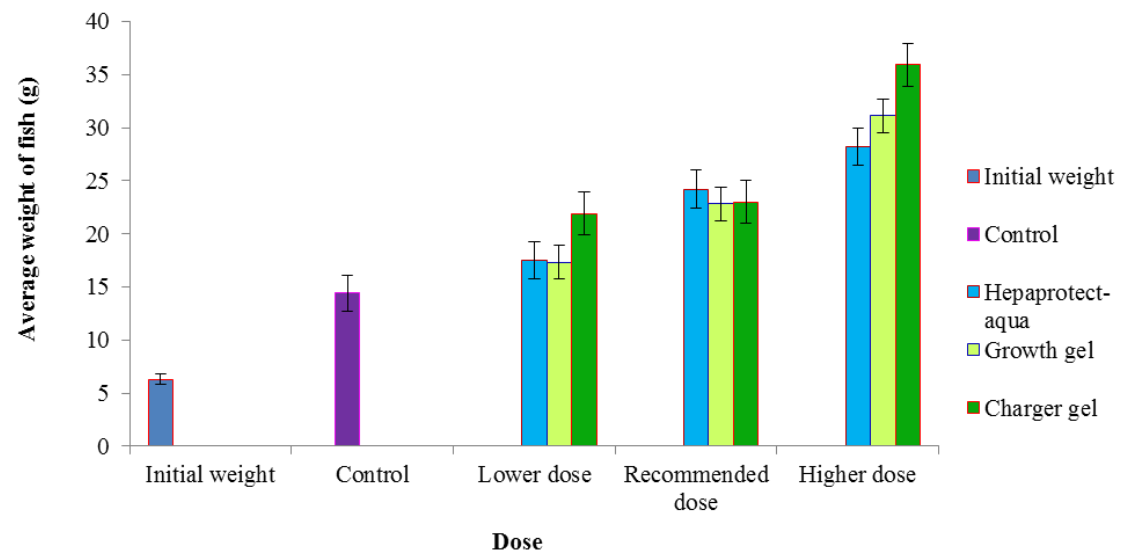

Figure 1. Comparative effect of three growth promoters to average growth of fish after 28 days.

\subsection{Average daily weight gain (g) of fish by three growth promoters}

The average daily weight gain of the experimental fish fed with growth promoter Charger gel with recommended dose, lower dose and higher dose were $0.60,0.56$ and $1.06 \mathrm{~g}$ respectively, with Growth gel, 0.59, 0.39 and $0.88 \mathrm{~g}$ respectively, with Hepaprotect-aqua, $0.64,0.40$ and $0.78 \mathrm{~g}$ respectively and without growth promoter (Control) was $0.29 \mathrm{~g}$ (Figure 2).

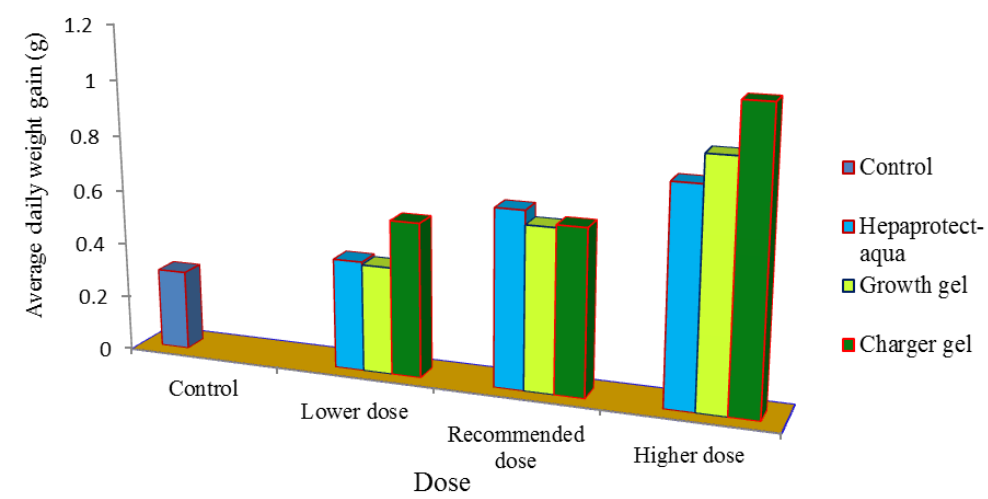

Figure 2. Average daily weight gain of fish using three growth promoters and without growth promoter (Control).

\subsection{Specific Growth Rate (SGR) of three growth promoters}

In case of recommended dose the average SGR by Charger gel, Growth gel and Hepaprotect-aqua were 2.01, 1.99 and $2.09 \%$ respectively, in case of lower dose, they were $1.93,1.57$, and $1.58 \%$ respectively, in case of higher dose, 2.70, 2.48 and 2.32\% respectively and in control, 1.28\% (Figure 3). 


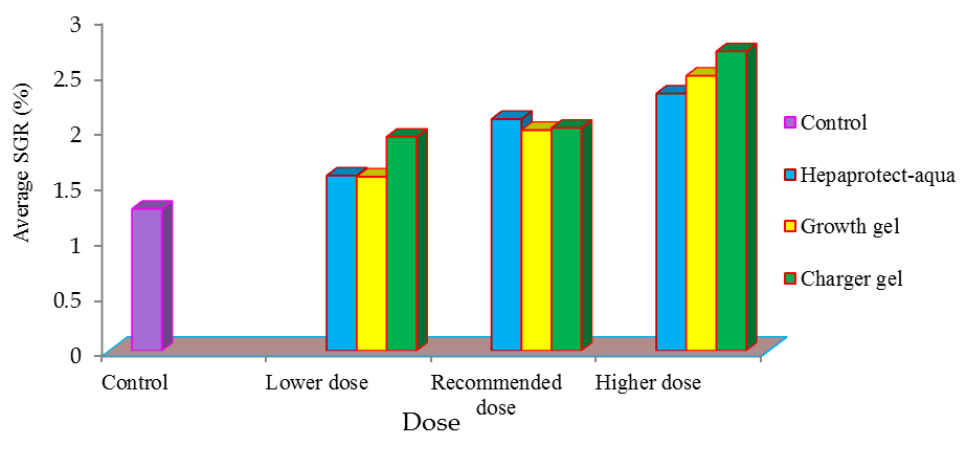

Figure 3. Comparison of average Specific Growth Rate (SGR) among three growth promoters.

\section{Discussion}

The growth promoters play an important role in growth, reproduction, development, survivals as well as feed consumption of fish. There is a close relationship between growth promoters and physical condition of fishes. Aqua-cultural production largely depends on suitable growth promoters if the dose and dosage are in accurate form. Otherwise it may hamper the production.

Aquaculture has a significance role in the economy of Bangladesh. Over the last decade it has expanded diversified, intensified and technologically improved. The development of aquaculture activities in Bangladesh are also influenced by a numbers of aqua-medicines, specially growth promoters.

The present investigation was conducted to know the performance of various growth promoters from some pharmaceutical companies, such as "Charger gel" from Fishtech (BD) Ltd., "Growth gel" from Advance Agrotech (BD) Ltd. and "Hepaprotect-aqua" from Renata Animal health Ltd.

The US FAD (food and drug administration) requires a scientific evaluation of drug's effectiveness and safety for human and environment before approval. Also the US EPA (environmental protection agency) requires a scientific evaluation of chemicals' safety before it can be registered and sold.

The present study was carried out to justify the recommended dose of particular growth promoters.

Charger gel is a growth promoter having a composition of 1-3D beta glucans, betain, and glycoproteins from yeast cell walls and from other natural sources. Beta 1-3D glucan is a potential, valuable, and promising immunostimulant for improving immune status and controlling diseases in fish culture (Robertsen, 1999). It is also effective in all mammals and birds with its immunoenhancing properties. It has applications for prophylactic and therapeutic use. It is used as an alternative to antibiotics and vaccines for protecting farmed fish against microorganisms, or parasitic disease. It's use together with vaccines to improve the effectiveness has become popular and it is non-toxic to fish. It also works well in conjoint therapy with other treatments (Rawles et al., 1997).

Betaine, a highly water soluble and therefore diffusible compound, stimulates the olfactory bulb of fish. It is found in relatively high quantities in marine invertebrates, microorganisms, and some plants (Meyers, 1987). Betaine is an effective attractant to several aquatic species. The main physiological or metabolic functions of betaine are related to osmoregulation and methyl donation. In fish, betaine can protect cells against dramatic changes in osmotic pressure. Betaine also helps prevent enzyme inhibition and plays an important role in tissues as a methyl donor in protein and energy metabolism.

Glycoproteins are proteins that have sugar molecules attached to them. These sugar molecules are actually gathered into short chains, or oligosaccharides. It helps to identify, adhere to and communicate with the cell, recognize cells and recognized immune system against foreign invaders and then defend against them. It also helps in reproduction.

Charger gel is manufactured by Growel Formulations Pvt. Ltd., Hyderabad, India and marketed in Bangladesh by Fishtech (BD) Ltd. According to manufacturer's instruction, benefits of Charger gel in fish were better utilization of feeds, improve FCR and weight gain, significant reduction of mortality, influence to build nonspecific immunity, and improve absorption of nutrients. Feeding trial of this feed additive in the tested catfish using three different treatments showed that after 28 days, growth performance with higher dose was found to be significantly higher than the other two doses (recommended and lower than recommended).

In the present study SGR was found to be significantly higher when Charger gel was incorporated in catfish diet at a rate of $100 \mathrm{mg} / 20 \mathrm{~g}$ feed/day. Further field level trials are necessary before its extensive use. 
Another growth promoter, Growth gel, had a composition of essential vitamins, lysine methionine \& herbs. It was manufactured by American Pharma International, Andhra Pradesh, India and marketed in Bangladesh by Advanced Agrotech (BD) Ltd. Manufacturer claimed that it could enhance metabolism and energy of fish body cells, raise the efficiency of feed utilization by supplying oxygen to whole body, improve better growth body weight, improve the immune responses, excrete heavy metals and make fish glossy, healthy \& active.

Fish need vitamins for health just like other animals. Vitamin A is essential for normal growth and development as well as for proper formation of bones and scales. Vitamin B-complex is necessary for proper growth, function of the nervous system, digestion of protein, and protection of the slime coat. Vitamin $\mathrm{C}$ is very important for disease prevention, healing, digestion, as well as proper formation of the skeleton. Vitamin D is a must for calcium and phosphorus metabolism which aids in normal development of bones and scales and Vitamin $\mathrm{K}$ aids in blood coagulation.

Lysine has one major function of protein deposition in animal. It is the second most limiting amino acid (Robinson and $\mathrm{Li}$, 2007). Adequate dietary lysine contents improve survival and growth rate and prevent erosion and deformities of fish dorsal, pectoral and ventral fin (Keembiyehetty and Gatlin, 1992). Lysine is beneficial to fish because it helps absorption of calcium, maintains healthy blood vessels, produces antibodies, enzyme, collagen and repair tissues. It also produces carnitine which helps to convert fatty acids into energy and maintain cholesterol in the blood.

Methionine is an essential amino acid for normal growth of fish (Ahmed et al., 2003). It takes part in protein synthesis and other important physiological functions (Zhou et al., 2006). Fish fed methionine added diet was reported to show improved growth performance, fish utilization and immune response (Rolland et al., 2015).

However, in the present study higher dose of Growth gel, $0.16 \mathrm{ml} / 20 \mathrm{~g}$ feed/day, showed better growth performance than the other two doses.

The third experimental feed additive, Hepaprotect-aqua, was manufactured by Renata Limited, Dhaka, Bangladesh and marketed in Bangladesh by Renata Animal health Ltd. It was a nutritional supplement by $\beta$ glucan, mannon polymer and essential oil. The company claimed that Hepaprotect-aqua could enhance and improve self-defense mechanism, enrich essential minerals and vitamin combinations for productivity and growth and treat liver disease. Vetvicka et al. (2013) reported that administration of $\beta$-glucan through immersion, dietary inclusion or injection was found to enhance many types of immune responses and resistance to bacterial and viral infections in many fish species.

Mannan oligosaccharide as nutritional supplements was found to be able to improve gastrointestinal health, overall health as well as wellbeing, energy levels and performance. Dimitroglou et al. (2010) showed that mannan oligosaccharide incorporated into live feeds retarded Vibrio species levels and could improve fish health and production. They also reported that mannan oligosaccharide improved growth performance and feed utilization in gilthead sea bream.

The recommended dose of this growth promoter, $30 \mathrm{mg} / 20 \mathrm{~g}$ feed/day, showed significantly higher rate of growth than the other two doses.

In the present experiment "Charger gel" from Fishtech (BD) Ltd, showed the best average result in the higher dose which was very much higher than other doses. Also "Growth gel" from Advance Agrotech (BD) Ltd. showed better performance of higher dose than the recommended and lower doses. So, the companies may carry out more researches in favor of their recommended doses.

Another growth promoter "Hepaprotect-aqua" from Renata Animal health Ltd. showed good result of recommended dose than higher one and lower dose.

\section{Conclusions}

In the present study three selected growth promoters Charger gel, Growth gel and Hepaprotect-aqua were used. For each growth promoters three dosages as recommended, higher and lower dose were applied to access the safe and effective dose which will give the best results than other as well as than the control section. All the three growth promoters showed better results at their higher doses in comparison to their results in lower and recommended doses. However, in average Charger gel showed the best result than the other two growth promoters. This information on the efficacy study of growth promoters needs to be disseminated to the farmers for improved fish production. Aquaculture is gradually coming in common practice in Bangladesh. Growth increment in aquaculture species can be of great value if the growth promoters are used properly. The results of the present work would be helpful for the aquaculture production in Bangladesh. 


\section{Acknowledgements}

The author would like to express his indebtedness and gratitude to his honorable teacher and supervisor Dr. M. Mamnur Rashid, Professor, Department of Aquaculture, Faculty of Fisheries, Bangladesh Agricultural University, Mymensingh for his wise guidance, scholastic advice, useful comment and unfailing enthusiasm throughout the whole period of this study.

\section{Conflict of interest}

None to declare.

\section{References}

Ahmed I, MA Khan and AK Jafri, 2003. Dietary methionine requirement of fingerling Indian major carp, Cirrhinus mrigala (Hamilton). Aquac. Int.,11: 449- 462.

Al-Mamun, 2013. Studies on the efficacy and growth performance of three most commonly used growth promoters from different pharmaceutical companies on pangus fish (Pangasianodon hypophthalamus) species. MS Thesis. Department of Fisheries Technology, Bangladesh Agricultural University, Mymensingh.

Ariful M, M Saim and M Alamgir, 2014. Safety dose of three commercially used growth promoters: nutricellaqua, hepaprotect aqua and rapid grow on growth and survival of Thai pangas (Pangasianodon hypophthalamus). J Coast Life Med., 2: 925-930.

Chandra KJ, AFMM Islam and DR Das, 2013. Effect of growth promoter (rapid grow) as a supplementation on the growth performance and feed utilization of monosex tilapia. International Research Journal of Applied Life Sciences, 2: 8-17.

Dimitroglou A, DL Merrifield, P Spring, J Sweetman, R Moate and SJ Davies, 2010. Effects of mannan oligosaccharide (MOS) supplementation on growth performance, feed utilisation, intestinal histology and gut microbiota of gilthead sea bream (Sparus aurata). Aquaculture, 300: 182-188.

Keembiyehetty CN and DM Gatlin, 1992. Dietary requirement of juvenile hybrid striped bass (Morone chrysops $\times$ M. saxatilis). Aquaculture, 104: 271-277.

Mahmud F, 2015. Efficacy of growth promoters from some pharmaceutical companies on tilapia (Oreochromis niloticus), MS Thesis, Department of Aquaculture, Bangladesh Agricultural University, Mymensingh.

Meyers SP, 1987. Aquatic feeds and chemo attractants. Aquaculture Information and fish Marketing Digest., $1 / 87$.

Rahman MM, MT Zaman and AM Islam, 2012. Efficacy test of growth promoters from some pharmaceutical companies on koi (Anabas testudineus) fish. Journal of Environmental Science \& Natural Resources, 7: 9398.

Rawles SD, A Kocabas, DM Gatlin III, WX Du and CI Wei, 1997. Dietary supplementation of Terramycin and Romet-30 does not enhance growth of channel catfish but does influence tissue residues. Journal of World Aquaculture Society, 28: 392-401.

Robertsen B, 1999. Modulation of the non-specific defense of fish by structurally conserved microbial polymers. Fish Shellfish Immunol., 9: 269-290.

Robinson EH and MH Li, 2007. Catfish protein nutrition. Mississippi State University, Bulletine No. 1159.

Rolland M, J Dalsgaard, J Holm, P Gómez-Requeni and PV Skov, 2015. Dietary methionine level affects growth performance and hepatic gene expression of GH- IGF system and protein turnover regulators in rainbow trout (Oncorhynchus mykiss) fed plant protein-based diets. Comparative Biochemistry and Physiology - Part B 181: 33-41.

Tacon AG, 2014. The nutrition and feeding of farmed fish and shrimp - a training manual 2. Nutrient sources and composition. Brasilia, Brazil: Food and Agriculture Organization of the United Nations.

Vetvicka V, L Vannucci and P Sima, 2013. The effects of $\beta$-glucan on fish immunity. N. Am. J. Med. Sci., 5: 580-588.

Zhou QC, ZH Wu, BP Tan, SY Chi and QH Yang, 2006. Optimal dietary methionine requirement for juvenile Cobia (Rachycentron canadum). Aquaculture, 258: 551-557. 